\title{
The Moderating Role of Market Mavens in Explaining the Impact of Brand Positioning Strategies on Brand Love
}

\author{
Saad Shahid * $\quad$ Sohail Zafar ${ }^{\dagger}$
}

\begin{abstract}
With the presence of increasingly similar products in the fashion apparel retail industry, the real challenge today is to steer marketing communication efforts in the direction of developing consumer-brand bonds that are interpersonal in nature, and also simultaneously acknowledging the role of market mavens as strong external influencers in this regard. Hence, the major area of focus this to analyze the relationship among three brand positioning strategies; feature, surrogate and benefit brand positioning strategy with brand love, while investigating the effect of market mavens on brand love and brand positioning. Building onto the extant literature, for the purpose of this study, a theoretical model is proposed and tested with survey data from 607 young consumers of private universities. All of the three brand positioning strategies show a significant relationship with brand love, which is moderated by an interpersonal influence of market mavens. However, the interaction effects of all three brand positioning strategies vary in strength. The results of the study also draw up a demographic profile of market mavens, suggesting that they are most likely to be female, well educated, slightly older consumers residing in metropolitan cities, thereby suggesting concrete practical implications towards the end.
\end{abstract}

Keywords: Brand positioning strategy, Brand love, Market maven.

\section{Introduction}

The importance of the concept of transmission of market information, through interpersonal communication has long been acknowledged by many researchers. These days, in particular, consumers do search for reviews and testimonials from influencers before they decide on making any buying decision (Deloitte, 2017). Consumers feel like they have a social responsibility to engage with other consumers and exchange their personal opinions, experiences and get up-to-date information about brands. It has been verified that consumers of fashion brands feel personally motivated to share brand information on social media in particular (Zollo, Filieri, Rialti, \& Yoon, 2020). Moreover, digital generation is most prone towards spending their disposable income on shopping from fashion brands and are also inclined towards social conversations. Rialti, Zollo, Laudano, and Ciappei (2018) emphasize the ability of knowledgeable consumers to contribute towards the co-creation of value for brands. In light of the interpersonal influences while making a purchase, there is an exclusive target group called market mavens who are individuals who have access to

\footnotetext{
${ }^{*}$ Lahore School of Economics, Burki Campus, Lahore, Pakistan.

${ }^{\dagger}$ Lahore School of Economics, Ringgold Standard Institution - Business, Lahore, Pakistan.
} 
information regarding several types of brands, shopping sites, price comparisons and other diverse market knowledge, and these market experts disseminate both consumer knowledge and industry information to potential customers. Three decades of research in the past have shown that brand managers have assessed and recognized the role of interpersonal sources of information, opinion leaders, early adopter and influence of several other reference groups in customer behavior. Market mavens, therefore, can be classified as a group of consumers that are similar in nature to other consumers, but differ in terms of magnitude of consumer market knowledge and depth of industry.

With the help of the market mavens, consumers tend to become more and perhaps even better informed, without having to get involved in conscious decision making (Wiedmann, Walsh, \& Mitchell, 2001). Since the increase in competition amongst brands has led to the need for brand managers to acknowledge the increasing importance of social gatherings, therefore, allowing market mavens to disseminate relevant brand information to potential consumer, are recognized for their role in their market based on consumerism. Extant literature shows support for marketing communications being responsible for communicating brand positioning. However, this does not undermine the external influence of market mavens in creating and helping to nourish a certain brand's positioning.

The total revenue for Pakistan's apparel retail industry was $\$ 8.7$ billion in 2014 , demonstrating an annual growth rate of $9.1 \%$ between 2010 and 2014 (Apparel Retail in Pakistan, 2016). High street fashion clothing retail brands are in a fierce competition across Pakistan. Moreover, the competition amongst fashion brands is both from local and international labels. In reality, there are too many fashion brands (see appendix I) offering the same generic products, for example, similar denim pants with different marketing campaigns. However, between 2014- 2019, the growth of the fashion apparel industry was expected to decline, with an anticipated compound annual growth rate of $7.5 \%$ (Apparel Retail in Pakistan, 2016). Given the forecasted turbulent time periods, fashion brands must be prepared to come face -to - face with marketing challenges that pertain to brand positioning strategy choices, market mavens and brand love.

The concern so as to how marketers can communicate information with market mavens has not been adequately addressed (Wiedmann et al., 2001). So far, influence of market mavens is studied in limited context, therefore, further quantitative research can be done to objectively estimate, and analyse the role that market mavens play. Therefore, this study proposes a theoretical framework, contextualizes it, and empirically tests the moderating role of market mavens between the brand positioning strategies (feature, surrogate and benefit brand positioning strategy) and brand love in Pakistan's context. Research by Wiedmann et al. (2001); Kiani, Laroche, and Paulin (2016) concluded that it shows a lack of detailed demographic profiling of market mavens. In conclusion, there is a lot yet unkown about consumer decision making process. As a result, not a lot is known about how these individuals approach decision making. Furthermore, there lacks consistency in prior literature about the demographic details of market mavens which has made it difficult for the brand executives to target market mavens. Therefore, this mostly disturbs the process of developing and communicating strategies that are in particularly aimed at influencing opinions of market mavens about different brands (Clark, Goldsmith, \& Goldsmith, 2008).

It is highly likely that in Pakistani fashion retail industry market mavens' role is rel- 
evant. This is primarily because it is a market that offers consumers a variety of brand choices and a plethora of information. Pressey and Barnes (2012) emphasize that market mavens are considered to be the most integral group of consumers, simply because of their ability to spread positive and/ or negative word-of-mouth through their broad social network hence leading them to become an important target consumer for brands (Slama, Nataraajan, \& Williams, 2015). This study is timely and relevant because market mavens are smart shoppers, information providers and advisors. It is true to some extent in accordance to saturated industries, in this case, the fashion retail industry (Williams \& Slama, 1995).

Research that is focused upon studying market mavens is now becoming increasingly, and widely popular in the domain of marketing. There are a few studies which have considered the demographic, and psychographic profiles of market mavens (Abratt, Nel, \& Nezer, 1995) their personality characteristics, the purchasing criteria that they adopt, the factors which motivate them to acquire the level of knowledge, and consequently practice the purchasing behaviors that they typically adopt (Chelminski \& Coulter, 2007; Clark \& Goldsmith, 2005), and lastly the characteristics of industrial market mavens. However, what is lacking in extant research is an obvious absence of an understanding of the moderating role of market mavens, especially when it comes to the relationship between three of the brand positioning strategies with brand love.

In light of the findings reported in extant literature and its pitfalls, this study aims to address three concerns; 1) What is the relationship of the three different brand positioning strategies (feature, surrogate and benefit brand positioning strategy) with brand love? 2) Do market mavens act as a moderating factor between brand positioning and brand love? and 3) What are the demographic characteristics of market mavens in the retail market for Pakistani high street fashion apparel? (See figure. 1)

\section{Theory Development and Hypotheses}

\section{Theoretical Perspective in Market Maven Research}

Market mavenism is an interdisciplinary concept, stemming from marketing, consumer behavior, communications, psychology, sociology and political science. These various disciplines authenticate that market mavens are existing, and that they provide a strong footing in acquiring and disseminating brand related facts or information. The pioneering researchers that developed the conceptual personality type which personifies market mavens. Williams and Slama (1995) explained market mavens as "Individuals who have information about many kinds of products, places to shop and other marketplace information such as special sales, usual prices, product quality and product variety". Table 1.1 summarizes various conceptual definitions of market mavens that have evolved over a period of time. Before the recognition of market mavens as a separate influential group, there were two traditional interpersonal influences which affected consumer behavior; early purchasers or adopters, and opinion leaders. 
Table 1.1

Definitions of Market Maven

\begin{tabular}{ll}
\hline Citation & Definition \\
\hline Feick and & $\begin{array}{l}\text { Individuals who have information about many kinds of products, places to shop } \\
\text { and other facets of markets and initiate discussions with consumers and respond to } \\
\text { Price (1987) }\end{array}$ \\
$\begin{array}{l}\text { requests from consumers for market information } \\
\text { Slama and }\end{array}$ & $\begin{array}{l}\text { places to shop and other marketplace information such as special sales, usual prices, } \\
\text { product quality and variety. }\end{array}$ \\
Williams (1990) & People who have high awareness \\
Elliott and & have information related to brands in a variety of industries \\
Warfield (1993) & $\begin{array}{l}\text { Individuals who intentionally convince or influence any other customers to create a } \\
\text { desirable attitude about a brand }\end{array}$ \\
Hoyer et al. & are called market mavens \\
\hline
\end{tabular}

Opinion leaders can be classified as personalities who take it upon themselves to provide information in the spectrum that lies between marketing initiatives and end consumers. The concept of an opinion leader is based on certain assumptions; these individuals provide information to the potential consumers or spread word about the product out of their own sheer involvement and interest in the product category, and interestingly, they are bound to a specific product category. The other interpersonal influence, i.e., the early purchasers, are highly likely to either have an active or a passive effect on later purchasers. Since the early purchasers are among the first few to use the product, their information is mostly driven by the actual use of the product. Early adopters and opinion leaders influence consumers primarily because of their brand specific knowledge. Interestingly, this influence is independent of the in - house marketing communications that are being practiced by fashion brands. The importance of the influence that early adopters can exert on consumers has been greatly emphasized in extant literature. The reason why opinion leaders might endorse a product can be a direct consequence of the influence that is exerted by early purchasers. Therefore, market mavens are different from influencers such as early adopters and opinion leaders, due to the simple reason that their activities revolve around broad market information rather than concerning a specific product category. At this point, it is necessary to contrast between the traits of early adopters, opinion leaders, and market mavens (Wiedmann et al., 2001), in order to comprehensively understand how market mavens categorically differ from the interpersonal influences that have been discussed prior to their introduction to the marketing and communications world (see table 1.2).

It is noteworthy here that market mavens accumulate and disseminate information on a wide variety of topics, and they believe it is their social obligation to spread the valuable information they have, perhaps, painstakingly possessed. The theories that aim to decode Market mavens, have been defined and presented completely in various extant researches (Katz \& Paul, 1955). However, not much is revealed about market mavens' demographic, psychographic and the behavioral traits.

Atkin (1972) found that the motivating factor behind market mavens spreading information about the product is their urge to engage with others on a social level. Some people get detailed access to market knowledge because they know it will prove useful to people around them. And interestingly, market mavens do this on purpose. Moreover, "market mavens serve as a useful means of distributing brand information often with greater credibility than many traditional marketing communications sources" (Barnes \& Pressey, 
2012). Sieber (1974) also pointed out a reason why market mavens might be keen about accumulating market information. His revelations point to the logical observation that this is to strengthen their societal standing by being more valuable to those with whom they get in touch and interact with. Table 1.3 shows the characteristics of market mavens in the fashion industry, as explained by Goldsmith, Flynn, and Goldsmith (2003).

Table 1.2

Early Adopters, Opinion Leaders, And Market Mavens

\begin{tabular}{|c|c|c|c|}
\hline & Early adopters & Opinion leaders & Market mavens \\
\hline Product Usage & Definitely & Yes & Not necessarily \\
\hline Product Usage & Definitely & Yes & Not necessarily \\
\hline General knowledge about the market & Definitely not & Definitely not & Definitely Yes \\
\hline Style of communication & $\begin{array}{l}\text { Mostly active/ } \\
\text { Sometimes not active }\end{array}$ & $\begin{array}{l}\text { Mostly active/ } \\
\text { Sometimes not active }\end{array}$ & Mostly active \\
\hline $\begin{array}{l}\text { Relevance based on the stage of the } \\
\text { product life cycle }\end{array}$ & Introduction & Pimarily Introduction & $\begin{array}{l}\text { Introduction, hrowth, maturity, } \\
\text { decline }\end{array}$ \\
\hline
\end{tabular}

Adapted from (Wiedmann, 2001)

Table 1.3

Characteristics of Market Maven

\begin{tabular}{ll}
\hline Characteristics & Market Mavens \\
\hline Information and knowledge & "Wide variety of market information. Information seekers." \\
Opinion Leadership & "Act as Opinion leaders for many aspects of the marketplace." \\
Search Behavior Involvement & "Exposed to a variety of information sources. Involved in many \\
& $\begin{array}{l}\text { aspects of the marketplace.? } \\
\text { "Heavy users of coupons shopping lists, grocery budgets and }\end{array}$ \\
Promotion & advertisements. \\
Brand Awareness & "Aware of new brands in many fields." \\
Assertiveness & "More assertive than other consumers." \\
Value conscious & "More value conscious than other consumers seek bargain." \\
Fashion Consciousness & "Market Mavens are not fashion conscious." \\
\hline Taken from Goldsmith et al. (2003)
\end{tabular}

\section{Relationship between Brand Positioning Strategies, Market Mavens and Brand Love}

\section{Brand Love:}

Brand love is a comparatively a newly created marketing concept which has been investigated by several researchers. In this regard, it has been revealed on several occasions that brand love has an influence on some of the most pivotal and critical marketing communications choices (Carroll \& Ahuvia, 2006; Batra, Ahuvia, \& Bagozzi, 2012). Fournier and Yao (1997) explained that consumers consider their brand relationship similar to that of their committed partner or best friends' relation.

It is believed that the basis of brand love which is how consumers build their relationship with a specific brand based on its features, symbolic attributes and personality, is present in the literature that revolves around the theory of brand positioning. The way consumers express themselves both socially and personally is the phenomenon of humanization of brands (Ahuvia, 2005). 
In this regard, brand love has been defined by Shimp and Madden (1988), as a concept which derives its basis from the interpersonal theories that are studied in psychology. Moreover, they also highlighted that the phenomenon of interpersonal love, and love for a product is, in fact, similar in nature. Triangular theory of development of love by Barnes and Pressey (2012) is a popular choice of framework that is applied, and referred to by researchers in order to explain the idea and concept of brand love. Shimp and Madden (1988) used the triangular theory of love, and further defined brand love as a concept that is fundamentally based on three definitive parts; liking, yearning and, commitment.

Ahuvia (2005) made a scale to quantitatively test the concept of brand love. He reported findings about the consumers' ability to love a brand, and its relationship with other relevant aspects of consumer behavior. Ahuvia (2005) also suggested that interpersonal love, and consumer-brand love are similar in nature. For example, consumers find certain brands attractive, and as a result, they desire to own such brands that are long lasting in terms of consumption and are a perfect fit to their personality. Moreover, consumers seem eager to invest resources in brands because they believe these brands to be a part of themselves. This perception aligns with Aron and Aron (1986)'s self-expansion theory with regards to brands in which familiarity/closeness is drawn graphically in a venn diagram representing an aura surrounding one's self to be overlapping with the aura and designated personality of the brand (MacInnis \& Folkes, 2017).

Batra et al. (2012), on the other hand, opposed the existence and similarity of interpersonal relationships which are associated with the consumer-brand bond. Batra et al. (2012) defend this perspective by stating that the consumer-brand love involves monetary exchanges, however, this is not the case with interpersonal love. They also conceptualized and empirically measured the concept of brand love, based on the understanding of the process which revolves around the blossoming of brand love among consumers. As a consequence, Batra et al. (2012) highlighted brand love as the consumers' emotional attachment to brands, and thereby categorized brand love as a set of cognitions, feelings and behaviors.

Despite the existence of different theoretical perspectives that surround the concept of brand love, there is a unanimous agreement with regards to the love that consumers can feel towards a brand, which then becomes an important aspect part of their life. Nevertheless, brand love is considered to be an important brand-consumer relationship variable, but still improvement in understanding the area of establishing and strengthening the relationship of love among a consumer and a brand is required.

Carroll and Ahuvia (2006) have suggested that brand love can be developed by adapting different brand positioning strategies, for example, these may include the product features and/ or the communicated and also availed benefits of the product. Hence, this view of brand love provides an additional reasoning behind conducting this study.

\section{Brand Positioning Strategies:}

The concept of branding is believed to be linked closely with that of brand positioning. Kapferer (2012) coined the phrase "brand as product", with the logic being that one cannot choose to ignore the brand as it is an integral part of the product, and also one cannot ignore the ability of brand positioning strategies to create a personal and perhaps powerful 
consumer-brand bond. Urde and Koch (2014) define "brand positioning as an inside-out approach that defines and implements an intended position with brand perception as its point of departure and continuing frame of reference". Dwelling further, brand positioning refers to "a consumer level perception of the brand and is based on the subjective attributes and images the consumers have about the brand in their memory structure". There are various ways of enveloping consumer response and one of them is to adopt an inside-out approach (Urde \& Koch, 2014), and the second way is the adoption of an external, outsidein approach, which implies that and individual relies on the attributes of market mavens to gather valuable market information.

The concept of benefit brand positioning has been highlighted and theoretically discussed by several academics in the past. It communicates the advantages of a brand; relates to the personal value customers allocate to a brand; is not observable; reflects if a brand performs as intended; and mostly, it implies attribute-based benefits, and also makes linkages to the solution of the problem (Crawford, 1985). Benefit brand positioning strategy also described as "Benefits that satisfy experiential/ hedonic needs; benefits that are psycho-social consequences out of the use of the product that have a hedonic, expressive, or symbolic function; benefits that give consumers an indirect advantage of the consumption of a product; benefits that enhance perception of a self-image or a social-image of consumers" (Crawford, 1985).

Furthermore, the personification of brands helps to identify with a brand in terms of having benefits that replicate those that are derived from humans, even when the imagery would not necessarily show a human-like attribute. The drive this personification offers is to ultimately provide experience of social and personal benefits to consumers that are enjoyed by using a particular brand. Another way to communicate benefit brand positioning strategy is to place the brand in such a manner that it shows that the brand is capable of replicating or furnishing human beings role in a social environment (MacInnis \& Folkes, 2017). Sometimes, brands can be placed in terms of the associative secondary benefits they offer, like achieving the role of a hero, and/or seemingly performing miracles that others brands are not capable of Mark and Pearson (2001). In this case, customers are likely to form a love-like, inseparable consumer-brand bond i.e. brand love with brands that are perceived by them as providing unparalleled benefits. Surrogate brand positioning strategy is one that is "designed to create consumer associations about external aspects of a brand; it says something about the brand that allows the consumer to come to individual conclusions; it does not emphasize attributes and benefits; it is aimed at creation of inferred (secondary) associations between consumers and brand; it refers to intangible aspects of the brand" (Crawford, 1985).

Giving a product the name of a human (Waytz, Heafner, \& Epley, 2014; Eskine \& Locander, 2014), explaining a product as if it is a person (Aggarwal \& McGill, 2007), and classifying the brand of having a gender accelerate the customers' abilities to anthropomorphize brands, and adopt surrogate positioning strategy, is a useful strategy in this regard. Research also suggests that customers can consider brands to be their authentic partners in real life, if only a brands communication is based on symbolic attributes or emotions that a brand is associated with Napoli, Dickinson, Beverland, and Farrelly (2014). Rocereto, and Kwak, Puzakova (2015) aimed to determine the impact of consumers' beliefs about 
brands having a mind of their own. Consumers are likely to perceive band as the most favorable if the brand is considered to have a mind of its own which ultimately creates an unbreakable consumer-brand bond of interpersonal love.

Another concept that is feature brand positioning strategy is classified and identified as an instance where the "company highlights the concrete attributes of the brand in order to create a differential advantage; concrete attributes are characteristics of the brand advantage; they are objectively measurable, mostly tangible and typically search features; these features are also specific to the product category" (Aaker \& Shansby, 1982; Hooley, Piercy, \& Nicoulaud, 2008; Plummer, 2000). In general, consumers' reaction towards brands highlighting its anthropomorphized features is more favorable (Kim \& Kramer, 2015). As a result, customers are more likely to consider a brand as dissimilar, similar, or related to different brands. Feature brand positioning strategy according to the research is based on anthropomorphized traits, tends to highlight the implication that the brand possesses a human-like mind (MacInnis \& Folkes, 2017).

\section{Moderating Effect of Market Mavens:}

Market maven is conceptually an influence which is external and has the potential to effect consumers' perception about brands, in particular when contrasted to the planned brand image which the brand managers have developed for the target group (Wangenheim \& Bayón, 2007). Influencers largely differ from market mavens with the way they approach communicating with their audience. Influencers, while creating engagement content keep their followers in mind, however, market mavens' content is driven by their knowledge of the market. Prior literature, mostly emphasizes on market mavens and relevant importance in accordance to moderating the relationship of customer satisfaction and brand loyalty (Anderson \& Mittal, 2000; Mittal \& Kamakura, 2001). Market mavens have also been studied as moderators in the context of marketing strategy, along with the big five personality model. Market mavens' role as a moderating aspect between the association of customer satisfaction, and new customer acquisition, has also been analyzed. Among many consumer-brand relationship studies in prior literature, brand satisfaction (Ahuvia, 2005), brand commitment, brand trust, (Chaudhuri \& Holbrook, 2001), brand passion, brand attachment (MacInnis \& Folkes, 2017) and brand connectedness, have been studied. In recent times, market mavens' role as moderators has been researched with consumer attitude, objective and subjective norms, and intentions to purchase brands. Brand love is proposed to be an important concept in marketing literature (Unal \& Aydin, 2013), and there has been a lack of research proposing an integrated model of brand positioning strategies, market mavens and brand love. Wangenheim and Bayón (2007) called market mavens as a 'marketplace influence', and suggested that they tend to act as a factor that presents a moderating effect between word-of-mouth and satisfaction. There is a greater tendency among market mavens to socially engage and give their independent expert opinion regarding a brand. Therefore, their influence in developing long-term relationship of consumers with a particular brand, via the positioning strategy, is critical. Walsh, Evanschitzky, and Wunderlich (2008, p. 6) support this view point and have stated that "the moderating role of consumer tendency to spread brand related information must gain its 
due importance by now". Market mavenism has been researched as a mediating construct as well (Laroche, Pons, Zgolli, Cervellon, \& Kim, 2003).

Market mavens are identified as a unique and niche consumer group. Prior literature in different contexts state that market mavens give an enhancing effect when it is about the relationship of independent variables and dependent variables. The presence of market mavens and the influence that they exercise in creating consumer-brand associations about different services and products, has been repeatedly confirmed and validated (Slama et al., 2015) this holds true for the international context (Abratt et al., 1995) as well as in the business-to-business context. Many researchers have urged that market mavens are more likely, as compared to others, to have product knowledge, and they will share it with third parties, independent of their level of product involvement. This self-imposed social responsibility of expressing their view point poses as a major threat to fashion retail brands, where in addition to the struggle of selecting the most effective brand positioning strategy, brand managers now have to be watchful of an external influence that is more likely to impact the creation of brand love. This study, therefore, proposes that brand positioning strategies (practiced by marketers to create associations in the consumers' minds) are likely impact the creation of interpersonal consumer-brand love. However, there might also be an indirect interaction of market mavens, and different brand positioning strategies on the development of brand love.

The following hypotheses summarize the discussion done so far:

H1: Market mavens moderate the relationship between benefit brand positioning strategy and brand love.

H2: Market mavens moderate the relationship between surrogate brand positioning strategy and brand love.

H3: Market mavens moderate the relationship between feature brand positioning strategy and brand love.

\section{Methodology}

\section{Unit of Analysis}

To empirically test the above stated hypotheses, a cross-sectional self- administered survey methodology was used. There are two justifications for selecting student sample. Firstly, to empirically examine the framework, this research takes into consideration consumers' perspective which has also been backed up by Fuchs (2008). In this regard, Prior research shows private university undergraduate and postgraduate students to be regular shoppers of fashion brands. Secondly, prior research on brand positioning have mostly used students as sample (Voss, Spangenberg, \& Grohmann, 2003). The survey responses from both undergraduate, and graduate students were collected. There was variability in the demographics of the surveyed population, based on their age, income and gender. A Sample of eight universities was randomly drawn from a pool of private universities in Pakistan. 
Questionnaires were shared with the program offices of the selected private universities. Questionnaires were also e-mailed to the prospective respondents from the sampling frame, where 607 were received back in a period of 6 weeks. The Sample size of 607 is justified by Bollen (1990), where it is mentioned that if the variables are reliable, and the theoretical model is not complex, even a sample size that is smaller than 607 could suffice.

\section{Instruments}

In order to maintain consistency with the previous research about brand positioning strategies, brand love and market mavens, the previously published measurement scales were re-worded, and adapted for the current study. Instrument for all three brand positioning strategies; feature, surrogate, and benefit brand positioning strategy has been taken from Fuchs (2008). Instrument of brand love has been adapted from Ahuvia (2005). The scale for market mavens is taken from Price and Feick (1987). The Instrument from Price and Feick (1987) was previously used in studies about market mavens (Ailawadi, Neslin, \& Gedenk, 2001; Barnes \& Pressey, 2012). Making use of the pre-developed and tested sacles ensure validity and reliability. The data was collected via emails as well as a URL embedded questionnaire (Wiedmann et al., 2001).

As stimuli for the respondents, print advertisements of the fashion apparel retail brands were used. The use of print advertisements, as stimuli, to brand positioning strategy survey research has been advocated in prior researches too (Blankson \& Kalafatis, 2004; Crawford, 1985). The objective of showing print advertisements as stimuli, was to convey the brand positioning of a particular brand's offerings. Prior literature justifies the use of print advertisements because of a widely accepted view that marketing communications are the tools to convey brand positioning, and the frequent use of advertisements as stimuli, in brand positioning research is common. The pool of print advertisements pertaining to fashion retail brands that were used for the purpose of this study, were similar to the ones used in the first and second study.

Before the print advertisements were made a part of the survey instrument as stimuli, their brand names were changed to fictitious brand names with the help of a design software, Adobe Photoshop CS6. This was primarily done to encourage respondents to base their survey responses only on the textual and visual brand positioning information presented in the print advertisements. This practice typically minimizes the confounding effects of the respondents' attitudes towards brand names that are already in their knowledge set. The questionnaire had three sections. The first section had stimuli print advertisements of fashion retail brands. The second section explained the objective of the study, along with identification of the respondent's most favorite fashion retail brand. Lastly, the third section of the survey had items that were relevant to the feature, surrogate, and benefit brand positioning strategy, brand love and market mavens. Fashion apparel retail high street brands were focused upon in this study. According to the Cambridge English Dictionary (2017), retail brands are those fashion brands which are readily accessible in fashion streets, shopping malls, and are completely different than the custom made fashion designer brands.

In behavioral science most of the researchers take into consideration common method 
bias problem. Common method variance is described as the "variance that is attributable to the measurement method rather than to the construct of interest. The term method refers to the form of measurement at different levels of abstraction, such as the content of specific items, scale type, response format, and the general context" (Fiske, 1982). Common method variance also has the ability to effect the relationships among different variables.

To measure the common method variance this research has used AMOS 22.0 software in order to avoid any effect common method bias can have on the research findings. Moreover, to test the presence and influence of the common method bias, the common latent factor test was used. For this purpose and to test hypothesis that for all the variance in the data collected only a single factor could be responsible, confirmatory factor analysis (CFA) was also performed (Iverson \& Maguire, 2000). Each from the constructs in the research were loaded on a single factor in order to establish the understanding whether most of the variance can be accounted for by one general factor or not.

In this regard, a single factor explained $29.3 \%$ of the variance in this model. The statistics of goodness-of-fit model indicate and propose a poor model fit as the indices were not below the generally accepted cut-off points; i.e., NFI $=0.464$, AGFI $=0.522$, the $\mathrm{CMIN} / \mathrm{DF}=6.83$ (cut-off point, 2 and 5 ), TLI $=0.501, \mathrm{RMSEA}=0.210$, and $\mathrm{CFI}=$ 0.482 .

All stated above the indicators have a cut-off point of 0.7 other than CMIN/ DF, and the RMSEA has to be less than 0.10 .

\section{Data Analyses}

\section{Confirmatory Factor Analysis}

To empirically test the model SEM (i.e Structural Equation Model) in AMOS 22.0 was instilled. The first step is Confirmatory Factor Analysis (CFA) in Structural Equation Modeling (SEM) followed by the testing of fit of the structural model. Model to be considered reliable, factor loadings are supposed to be higher than 0.70 (see table 1.4). CFA also recognized unidimesionality of all the items involved. For all the constructs used in this research CFA was performed; that is to say feature, surrogate, and benefit brand positioning strategy, brand love and also for market mavens.

To measure the model fit, the values of goodness-of-fit (GFI), comparative fit index (CFI), normed fit index (NFI), adjusted goodness-of-fit index (AGFI) and Tucker Lewis Index (TLI) were used. The acceptable range for the model fit indices is essentially between 0 and 1, with values closer to 1 indicating a good model fit (Hair, 2009). The value of the root mean square error of approximation (RMSEA) should be less than 0.1, and the CMIN/DF should be between 2 and 5 (Yang, 2010). See table 1.4 for the factor loadings, Cronbach's alpha (scale reliability), composite reliability (CR), goodness-of-fit statistics and average variance extracted of the proposed measurement model. Any value of Cronbach's alpha above 0.70 is considered to be good measure for unidimensionality of the latent constructs (Nunnally \& Bernstein, 1994). No items were dropped since all the factor loadings were greater than 0.70. Furthermore, the Composite Reliabilities were 
not below the cut-off point of 0.70 (Nunkoo \& Ramkissoon, 2012), and this measure is considered to be a superior test of reliability than the Cronbach's alpha (Hair, 2009).

\begin{tabular}{|c|c|c|c|c|}
\hline Factor and Item & F.L. & Cronbach's Alpha & CR & AVE \\
\hline Benefit Positioning & & 0.771 & 0.769 & 0.539 \\
\hline BP1 & 0.881 & & & \\
\hline BP2 & 0.711 & & & \\
\hline BP3 & 0.713 & & & \\
\hline BP4 & 0.876 & & & \\
\hline BP5 & 0.852 & & & \\
\hline BP6 & 0.698 & & & \\
\hline cool & & & & \\
\hline Surrogate Positioning & & 0.761 & 0.782 & 0.515 \\
\hline SP1 & 0.762 & & & \\
\hline SP2 & 0.799 & & & \\
\hline SP3 & 0.779 & & & \\
\hline SP4 & 0.716 & & & \\
\hline SP5 & 0.81 & & & \\
\hline Feature Positioning & & 0.777 & 0.759 & 0.599 \\
\hline FP1 & 0.779 & & & \\
\hline FP2 & 0.851 & & & \\
\hline FP3 & 0.695 & & & \\
\hline FP4 & 0.791 & & & \\
\hline Brand Love & & 0.789 & 0.741 & 0.518 \\
\hline FP1 & 0.744 & & & \\
\hline FP2 & 0.817 & & & \\
\hline FP3 & 0.734 & & & \\
\hline FP4 & 0.767 & & & \\
\hline FP5 & 0.712 & & & \\
\hline FP6 & 0.791 & & & \\
\hline FP7 & 0.739 & & & \\
\hline FP8 & 0.7 & & & \\
\hline FP9 & 0.783 & & & \\
\hline FP10 & 0.717 & & & \\
\hline Market Maven & & 0.764 & 0.703 & 0.598 \\
\hline MM1 & 0.698 & & & \\
\hline MM2 & 0.793 & & & \\
\hline MM3 & 0.811 & & & \\
\hline MM4 & 0.932 & & & \\
\hline MM5 & 0.792 & & & \\
\hline MM6 & 0.783 & & & \\
\hline
\end{tabular}

The Average variance extracted (AVE) for the variables turned out to be above 0.5. Meaning the constructs used in this study have convergent validity, and these latent constructs were indicated by the measured items that reflected well the theoretical latent constructs that were taken into consideration. These results indicate that the convergent validity and reliably of the scale is good. Table 1.5 represents the discriminant validity of every construct included in the study. With the square root of the AVE of constructs, correlations of a construct along with all other constructs were compared (Chin et al., 1998). For discriminant validity to sustain, it is necessary that the number in each column and row do not have to be higher than the numbers in the parenthesis of that column and 
row; and table 1.5 highlights that the condition was met by all the latent constructs in this study.

Table 1.5
\begin{tabular}{lccccccc} 
The Demographic Characteristics of Administrative Staff $(\mathrm{n}=202)$ & \\
\hline Constructs & Mean & S.D. & BP & SP & FP & BL & MM \\
\hline BP & 3.21 & 0.781 & -0.734 & & & & \\
SP & 2.84 & 1.03 & $0.32^{* *}$ & -0.717 & & & \\
FP & 3.06 & 1.22 & $0.33^{* *}$ & $0.30^{* *}$ & -0.774 & & \\
BL & 4.09 & 1.08 & $0.39^{* * *}$ & $0.41^{* *}$ & $0.17^{* *}$ & -0.719 & \\
MM & 3.87 & 1.35 & $0.29^{* *}$ & $0.34^{* *}$ & $0.41^{* *}$ & $0.37^{* *}$ & -0.773 \\
\hline **Correlation is significant at the 0.05 level (2-tailed).
\end{tabular}

The square root of AVE can be seen by statistics in the parenthesis on the diagonal. For discriminant validity to sustain, it is necessary that the number in each column and row do not have to be higher than the numbers in the parenthesis of that column and row.

\section{Structural Model, Results and Discussion}

In order to verify whether market mavens have a moderating effect on the relationship between the three brand positioning strategies and brand love, a moderation analysis was conducted. The results of analysis reveal that as the value for moderating factor changes, the nature of the relationship between brand love and brand positioning strategy changes. The moderating effect of market mavens could be enhancing, where the increase in the moderator variable would strengthen the relationship between brand love and brand positioning strategy; often buffering where the increase in the moderator variable would weaken the relationship among a brand positioning strategy and brand love; or even antagonistic, where an increase in the values of the moderator would reverse the relationship among a brand positioning strategy and brand love. Previous studies of market mavens show an increasing, external effect among the relationship between buyer behavior and brand positioning.

A moderation analysis was done for three separate models; 1) Model 1 (M1) estimated the standardized beta coefficient between brand love and benefit brand positioning strategy. M1 also estimated the standardized beta coefficient when it comes to the interaction effect of the benefit brand positioning strategy with the market maven on brand love, 2) Model 2 (M2) estimated the standardized beta coefficient between brand love and surrogate brand positioning strategy. M2 also estimated the standardized beta coefficient for the interaction effect of surrogate brand positioning strategy with the market maven on brand love, and 3) Model 3 (M3) estimated the standardized beta coefficient between brand love and feature brand positioning strategy. M3 also estimated the standardized beta coefficient for the interaction effect of the feature brand positioning strategy with market maven on brand love (see table 1.6). The first part of analyzing the data is to test the structural model and estimate the relationships of all three strategies; feature, surrogate, and benefit brand positioning strategy, with brand love without presence of market mavens as a moderating factor. In this case, all the variables were standardized. The interaction variables (namely; the benefit positioning $\mathrm{x}$ market maven, the surrogate positioning $\mathrm{x}$ market maven and 
feature brand positioning strategy), alongside the external influence of market mavens, brand love is expected to rise to a higher level. The results showed similar patterns for the interaction effect of surrogate positioning and market mavens on brand love. If the fashion brands' positioning is based on intangible attributes of the product, combined with an increased external influence of market mavens, the creation of an interpersonal love-like consumer-brand bond is likely to be stronger.

This study, moreover, provides details about the demographic profile of market mavens in the fashion retail industry (see table 1.7). Descriptive statistics show that these individuals are mostly females, are generally well educated, and tend to be slightly older consumers. Market mavens reside in the metropolitan cities of Pakistan such as Lahore, Karachi and Islamabad. The location findings are in line with the research findings of (Kontos, Emmons, Puleo, \& Viswanath, 2011). The study also highlights that market mavens, knowledge experts of fashion brands are most likely to be females, i.e 59\%. Furthermore, these findings also show that market mavens, in the modern day and age, have a more complex profile. In this regard, this study supports and validates the findings of Geissler and Edison (2005), especially when it emphasizes on the notion that a more precise identification and demographic profiling of market mavens is likely to be helpful for marketers.

Table 1.7

Market Mavens' Profile

\begin{tabular}{ll}
\hline Market Maven Profile Characteristics & \\
\hline Gender & \\
Male & $41.0 \%$ \\
Female & $51.0 \%$ \\
Age & \\
$<24$ years & $26.9 \%$ \\
$25-29$ years & $38.1 \%$ \\
$30-34$ years & $13.8 \%$ \\
35 - 39 years & $11.6 \%$ \\
$>40$ years & $9.60 \%$ \\
Marital Status & \\
Married & $7.00 \%$ \\
Single & $93.0 \%$ \\
City of Residence & \\
Lahore & $33.8 \%$ \\
Karachi & $25.1 \%$ \\
Islamabad & $17.1 \%$ \\
Others & $24.0 \%$ \\
Education & \\
Bachelor's degree or equivalent & $48.2 \%$ \\
Master's degree or equivalent & $39.7 \%$ \\
Doctoral degree or equivalent & $12.1 \%$ \\
\hline
\end{tabular}

The findings of this study reveal that market mavens prove to be a significant external influence in strengthening the relationship of brand positioning strategies with brand love, when it comes to high street fashion retail brands. Moreover, these findings are true for all three brand positioning strategies that were investigated for the purpose of this research (namely; feature, surrogate, and benefit brand positioning strategy). In this regard, marketing communication tools may effectively help to communicate brand positioning (Blankson \& Kalafatis, 2004), however, these tools are part of the internal marketing ef- 
forts by brand managers. This study empirically tests the effects of the interaction between the internal marketing efforts (three brand positioning strategies), and the external interpersonal influences, (market mavens) on brand love. As established, the brand positioning is likely to be based on tangible features, or perceived benefits, or intangible symbolic attributes of a brand, for example, the name of the designer who is associated with the brand. However, the external interpersonal influence of an informed and socially recognized consumer is still likely to have a positive influence on the development of a long lasting brand love among consumers of fashion retail brands.

These findings are in line with the findings of Berman (2016). He explained that a recommendation from an influential person is given more importance and weightage by consumers, than a planned message communicated via a paid advertisement. Out of the three brand positioning strategies, the impact on brand love, due to the interaction between the surrogate brand positioning strategy and market maven $(\beta 5=.461, \mathrm{p}<.01)$, took a middle ground position. The least effect left on brand love is due to the interaction between the benefit brand positioning strategy and market mavens $(\beta 4=.380, \mathrm{p}<.01)$. The most significant impact on brand love was due to the interaction between the feature brand positioning strategy and market mavens $(\beta 6=.618, \mathrm{p}<.01)$. The revelations about the positive impact due to the interaction between the benefit brand positioning strategy, and market mavens, are consistent with those reported by Pons, Cervellon, Zgolli, Laroche, \& Kim (2003). The consumers whose perceptions about a fashion brand are due to the association shaped by the interaction of the feature brand positioning strategy and market maven, are more likely to develop into a long lasting love-like, consumer-brand bond.

Fashion brands, which have the ability to identify market mavens, and consider their capability of being able to alter the extent to which consumers will feel attached to a particular brand, are more likely to achieve success in the fashion retail industry. Essentially, this study emphasizes that fashion brands' managers need to focus, not only on the communication which incorporates brand positioning, with the help of internally created advertising initiatives, but they also need to focus on finding out the best possible ways to communicate, and leave a positive influence on market mavens. This is because market mavens have the ability to influence the creation of long-term consumer-brand bonds.

\section{Managerial Implications}

The consideration of the importance of the interactions of market mavens, with the choice of the different brand positioning strategies, and the resultant positive effect of such interactions on brand love, has several implications for high street fashion retail brands and brand managers. Firstly, marketers must realize that market mavens are capable of swaying people's opinions about a fashion brand, both ways, i.e., they can either have a positive or a negative influence on potential consumers. Their word-of-mouth can have an impact on the product choice of consumers (Kiel \& Layton, 1981), making their role, a critical issue to consider. Secondly, potential market mavens must be identified and targeted by brand managers for them to be the disseminators of product information. Thirdly, fashion brands must be aware of the involvement of market mavens, and their ability to share product information with others. Fourthly, if brand managers focus their marketing initiatives 
on feature brand positioning strategy, along with an effort to approach market mavens for positive collaborations, it is highly likely that a long lasting, idealistic consumer-brand bond will be created, then in the case if other brand positioning strategies are considered. Market mavens must be communicated the unique features of the fashion brand, which will urge them to socially talk about the brand in a positive light. Lastly, brand managers must develop and disseminate content which makes it compelling for market mavens to voluntarily initiate a social conversation with the target group. The communications can be about the unique features of the product.

\section{Limitations and Future Research Direction}

This study is a step forward towards an integrated and systematic analysis of the three brand positioning strategies, market mavens and brand love. However, it is subject to several limitations, and provides indications to interesting future research directions. Firstly, the influence and behavior of market mavens can be studied across multiple channels of communications (on-line and traditional) (Barnes \& Pressey, 2012). Secondly, a comparison between the types of marketing channels can be made, in order to understand the most effective way to communicate with market mavens. Thirdly, while this study has added to the understanding of the demographic profile of market mavens in Pakistan, still, investigation about personal characteristics, interests, values and the motivating factors of

Figure 1

Structural Model of Moderation

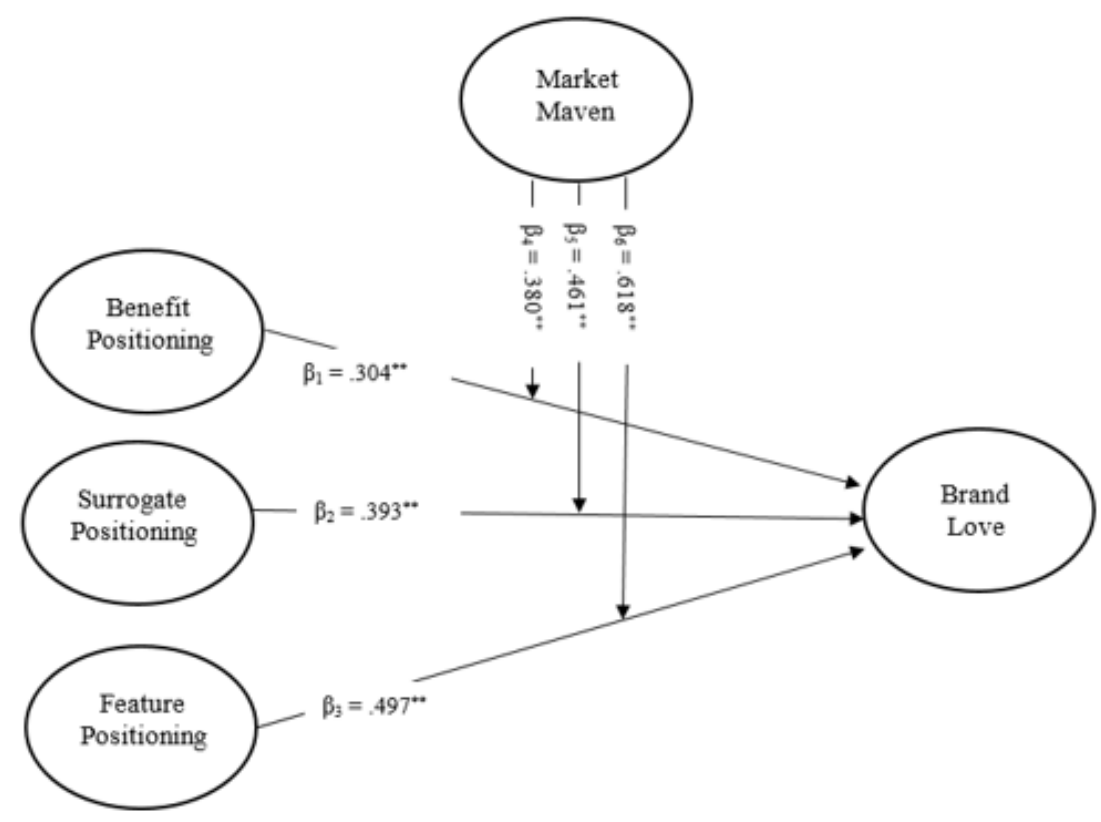


market mavens would be valuable in enhancing our understanding about this important group of consumers. Fourthly, another interesting dimension of the study could be to understand market mavens' role in prospective to online shopping, given that the online shopping and social has now influenced in the development of long lasting consumer-brand bond.

\section{Figure 2}

Interactive Effect of Benefit Positioning and Market Maven on Brand Love

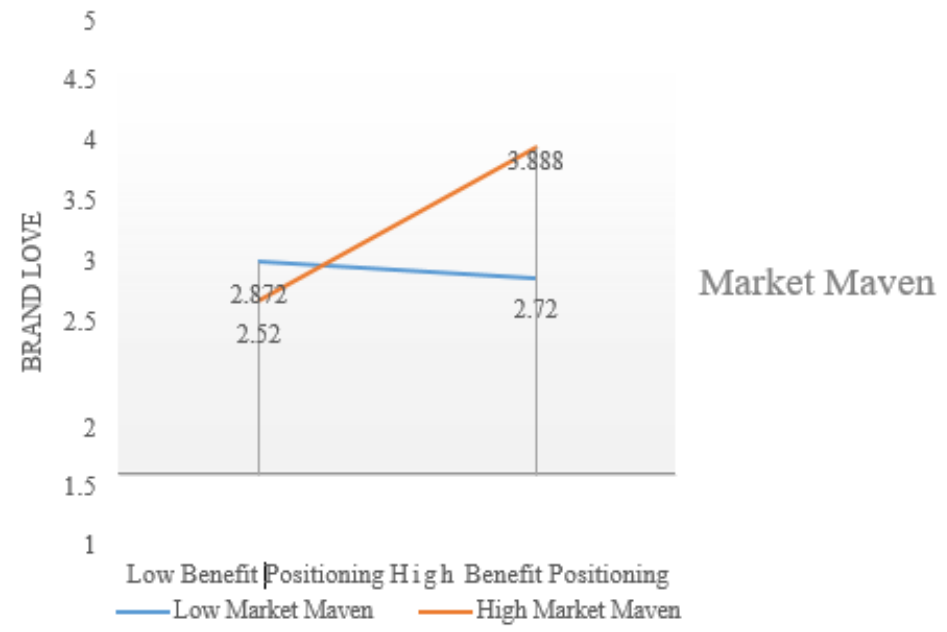

Figure 3

Interactive Effect of Surrogate Positioning and Market Maven on Brand Love

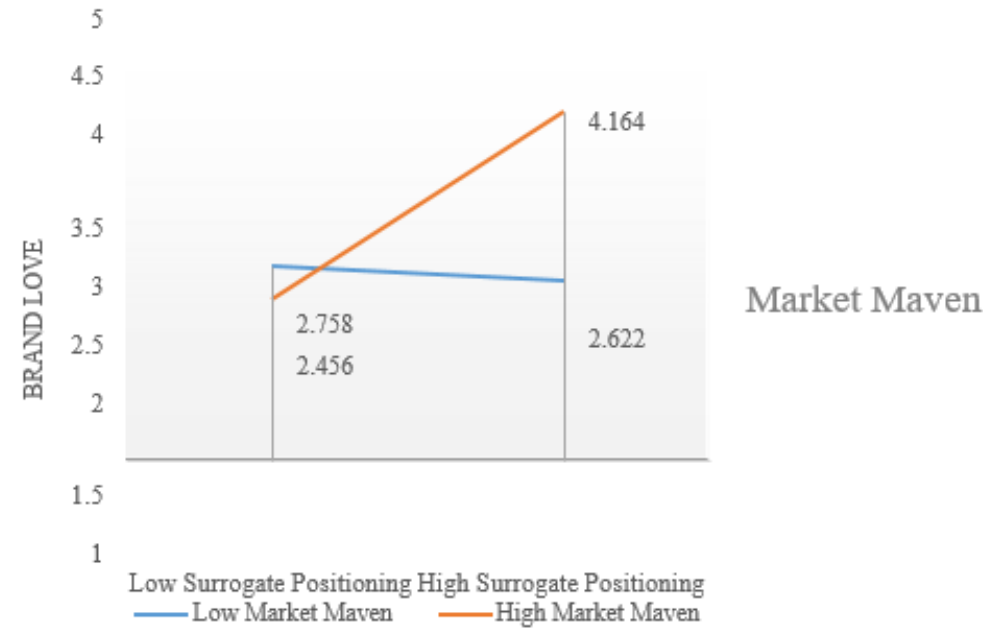

Also, this perspective has been examined by Mangal and Drave (2018), where they have 
highlighted that market mavens are highly involved with electronic retailing. Lastly, market mavens must be studied in countries other than Pakistan to add generalizability and comprehensiveness to the research. Moreover, cross-cultural studies can also provide insights into market mavens from developing and developed countries. Lastly, market mavens' behavior might vary amongst different cultures (Swaminathan, Stilley, \& Ahluwalia, 2009). Therefore, it is expected that a cross-cultural study on understanding the effects of the interactions of market mavens, and the brand positioning strategies on brand love across different cultures, in the perspective of multiple product categories, will ultimately prove to be useful.

\section{Figure 4}

Interactive Effect of Feature Positioning and Market Maven on Brand Love

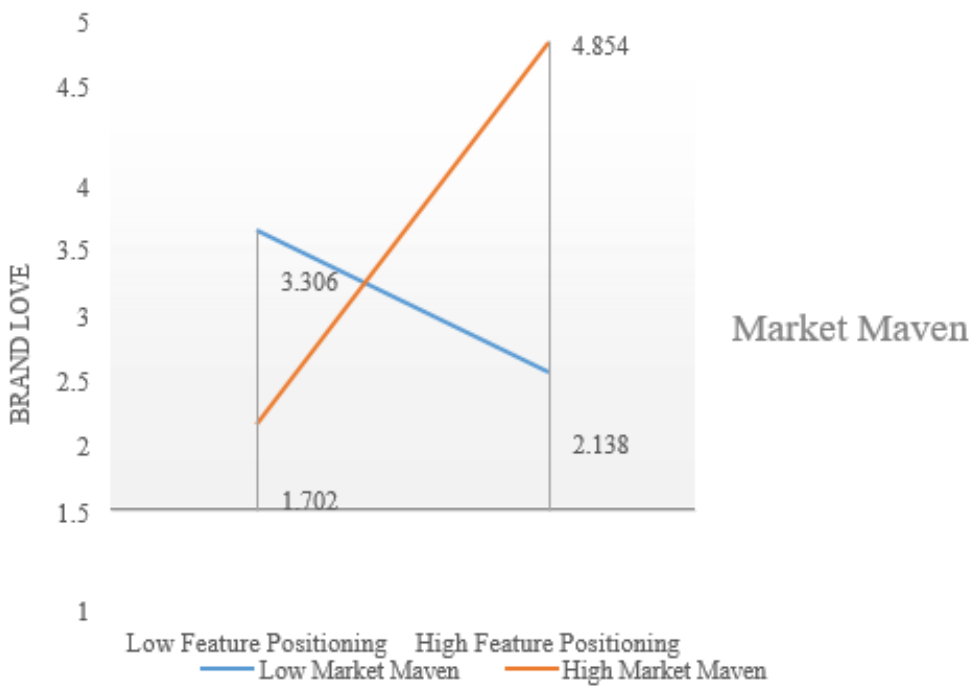




\section{References}

Aaker, D. A., \& Shansby, J. G. (1982). Positioning your product. Business Horizons, $25(3), 56-62$.

Abratt, R., Nel, D., \& Nezer, C. (1995). Role of the market maven in retailing: A general marketplace influencer. Journal of Business and Psychology, 10(1), 31-55.

Aggarwal, P., \& McGill, A. L. (2007). Is that car smiling at me? Schema congruity as a basis for evaluating anthropomorphized products. Journal of Consumer Research, $34(4), 468-479$.

Ahuvia, A. C. (2005). Beyond the extended self: Loved objects and consumers' identity narratives. Journal of Consumer Research, 32(1), 171-184.

Ailawadi, K. L., Neslin, S. A., \& Gedenk, K. (2001). Pursuing the value-conscious consumer: Store brands versus national brand promotions. Journal of Marketing, 65(1), $71-89$.

Anderson, E. W., \& Mittal, V. (2000). Strengthening the satisfaction-profit chain. Journal of Service Research, 3(2), 107-120.

Aron, A., \& Aron, E. N. (1986). Love and the expansion of self: Understanding attraction and satisfaction. Hemisphere Publishing Corp/Harper \& Row Publishers.

Atkin, C. K. (1972). Anticipated communication and mass media information-seeking. Public Opinion Quarterly, 36(2), 188-199.

Barnes, S. J., \& Pressey, A. D. (2012). In search of the meta-maven: An examination of market maven behavior across real-life, web, and virtual world marketing channels. Psychology \& Marketing, 29(3), 167-185.

Batra, R., Ahuvia, A., \& Bagozzi, R. P. (2012). Brand love. Journal of Marketing, 76(2), $1-16$.

Blankson, C., \& Kalafatis, S. P. (2004). The development and validation of a scale measuring consumer/customer-derived generic typology of positioning strategies. Journal of Marketing Management, 20(1-2), 5-43.

Bollen, K. A. (1990). Overall fit in covariance structure models: Two types of sample size effects. Psychological Bulletin, 107(2), 256.

Carroll, B. A., \& Ahuvia, A. C. (2006). Some antecedents and outcomes of brand love. Marketing Letters, 17(2), 79-89.

Chaudhuri, A., \& Holbrook, M. B. (2001). The chain of effects from brand trust and brand affect to brand performance: The role of brand loyalty. Journal of Marketing, 65(2), 81-93.

Chelminski, P., \& Coulter, R. A. (2007). On market mavens and consumer self-confidence: A cross-cultural study. Psychology $\&$ Marketing, 24(1), 69-91.

Chin, W. W., et al. (1998). The partial least squares approach to structural equation modeling. Modern Methods for Business Research, 295(2), 295-336.

Clark, R. A., \& Goldsmith, R. E. (2005). Market mavens: Psychological influences. Psychology \& Marketing, 22(4), 289-312.

Clark, R. A., Goldsmith, R. E., \& Goldsmith, E. B. (2008). Market mavenism and consumer self-confidence. Journal of Consumer Behaviour: An International Research Review, $7(3), 239-248$. 
Crawford, C. M. (1985). A new positioning typology. Journal of Product Innovation Management: An International Publication of the Product Development 85 Management Association, 2(4), 243-253.

Deloitte, L. (2017). Bling it on: What makes a millennial spend more. Retrieved from https://www2.deloitte.com/content/dam/Deloitte/uk/Documents/ consumer-business/deloitte-uk-young-luxury-shopper-2017.pdf .

Eskine, K. J., \& Locander, W. H. (2014). A name you can trust? Personification effects are influenced by beliefs about company values. Psychology $\& 3$ Marketing, 31 (1), 48-53.

Fiske, D. W. (1982). Convergent-discriminant validation in measurements and research strategies. Jossey-Bass Publishers, Inc.

Fournier, S., \& Yao, J. L. (1997). Reviving brand loyalty: A reconceptualization within the framework of consumer-brand relationships. International Journal of research in Marketing, 14(5), 451-472.

Fuchs, C. (2008). Brand positioning through the consumers' lens (doctoral dissertation, uniwien).

Geissler, G. L., \& Edison, S. W. (2005). Market mavens' attitudes towards general technology: Implications for marketing communications. Journal of Marketing Communications, $11(2), 73-94$.

Goldsmith, R. E., Flynn, L. R., \& Goldsmith, E. B. (2003). Innovative consumers and market mavens. Journal of Marketing Theory and Practice, 11(4), 54-65.

Hair, J. F. (2009). Multivariate data analysis. Prentice Hall, Upper Saddle River.

Hooley, G. J., Piercy, N., \& Nicoulaud, B. (2008). Marketing strategy and competitive positioning. Pearson Education.

Iverson, R. D., \& Maguire, C. (2000). The relationship between job and life satisfaction: Evidence from a remote mining community. Human Relations, 53(6), 807-839.

Kapferer, J.-N. (2012). The new strategic brand management: Advanced insights and strategic thinking. Kogan page publishers.

Katz, E., \& Paul, F. (1955). Lazarsfeld, personal influence, glencoe, ill. Free Press.

Kiani, I., Laroche, M., \& Paulin, M. (2016). Development of market mavenism traits: Antecedents and moderating effects of culture, gender, and personal beliefs. Journal of Business Research, 69(3), 1120-1129.

Kiel, G. C., \& Layton, R. A. (1981). Dimensions of consumer information seeking behavior. Journal of marketing Research, 18(2), 233-239.

Kim, H. C., \& Kramer, T. (2015). Do materialists prefer the brand-as-servant? the interactive effect of anthropomorphized brand roles and materialism on consumer responses. Journal of Consumer Research, 42(2), 284-299.

Kontos, E. Z., Emmons, K. M., Puleo, E., \& Viswanath, K. (2011). Determinants and beliefs of health information mavens among a lower-socioeconomic position and minority population. Social Science \& Medicine, 73(1), 22-32.

Laroche, M., Pons, F., Zgolli, N., Cervellon, M.-C., \& Kim, C. (2003). A model of consumer response to two retail sales promotion techniques. Journal of Business Research, 56(7), 513-522.

MacInnis, D. J., \& Folkes, V. S. (2017). Humanizing brands: When brands seem to be like me, part of me, and in a relationship with me. Journal of Consumer Psychology, 
$27(3), 355-374$.

Mark, M., \& Pearson, C. S. (2001). The hero and the outlaw. McGraw-Hill.

Mittal, V., \& Kamakura, W. A. (2001). Satisfaction, repurchase intent, and repurchase behavior: Investigating the moderating effect of customer characteristics. Journal of Marketing Research, 38(1), 131-142.

Napoli, J., Dickinson, S. J., Beverland, M. B., \& Farrelly, F. (2014). Measuring consumerbased brand authenticity. Journal of Business Research, 67(6), 1090-1098.

Nunkoo, R., \& Ramkissoon, H. (2012). Structural equation modelling and regression analysis in tourism research. Current Issues in Tourism, 15(8), 777-802.

Nunnally, J. C., \& Bernstein, I. (1994). Validity. Psychometric theory, 3, 99-132.

Plummer, J. T. (2000). How personality makes a difference. Journal of Advertising Research, 40(6), 79-83.

Rialti, R., Zollo, L., Laudano, M. C., \& Ciappei, C. (2018). Social media brand communities and brand value co-creation: Evidences from italy. Mercati \& Competitività.

Satorra, A., \& Bentler, P. M. (2001). A scaled difference chi-square test statistic for moment structure analysis. Psychometrika, 66(4), 507-514.

Shimp, T. A., \& Madden, T. J. (1988). Consumer-object relations: A conceptual framework based analogously on sternberg's triangular theory of love. ACR North American Advances, 15(1), 163-168.

Sieber, S. D. (1974). Toward a theory of role accumulation. American Sociological Review, $567-578$.

Slama, M., Nataraajan, R., \& Williams, T. G. (2015). Market mavens and the relationship between smart buying and information provision: An exploratory study. In Proceedings of the 1992 Academy of Marketing Science (AMS) Annual Conference (pp. 90-93).

Swaminathan, V., Stilley, K. M., \& Ahluwalia, R. (2009). When brand personality matters: The moderating role of attachment styles. Journal of Consumer Research, 35(6), 985-1002.

Unal, S., \& Aydın, H. (2013). An investigation on the evaluation of the factors affecting brand love. Procedia-Social and Behavioral Sciences, 92, 76-85.

Urde, M., \& Koch, C. (2014). Market and brand-oriented schools of positioning. Journal of Product \& Brand Management, 23(7), 478-490.

Voss, K. E., Spangenberg, E. R., \& Grohmann, B. (2003). Measuring the hedonic and utilitarian dimensions of consumer attitude. Journal of Marketing Research, 40(3), $310-320$.

Wangenheim, F. V., \& Bayón, T. (2007). The chain from customer satisfaction via wordof-mouth referrals to new customer acquisition. Journal of the Academy of Marketing Science, 35(2), 233-249.

Waytz, A., Heafner, J., \& Epley, N. (2014). The mind in the machine: Anthropomorphism increases trust in an autonomous vehicle. Journal of Experimental Social Psychology, 52, 113-117.

Wiedmann, K.-P., Walsh, G., \& Mitchell, V.-W. (2001). The mannmaven: An agent for diffusing market information. Journal of Marketing Communications, 7(4), 195-212. 
Williams, T. G., \& Slama, M. E. (1995). Market mavens' purchase decision evaluative criteria: Implications for brand and store promotion efforts. Journal of Consumer Marketing, 12(3), 4-21.

Zollo, L., Filieri, R., Rialti, R., \& Yoon, S. (2020). Unpacking the relationship between social media marketing and brand equity: The mediating role of consumers' benefits and experience. Journal of Business Research, 117, 256-267. 